\title{
Exploration and Augmentation of Pharmacological Space via Adversarial Auto-encoder Model for Facilitating Kinase-centric Drug Development
}

Research article

Keywords:

Posted Date: November 19th, 2020

DOl: https://doi.org/10.21203/rs.3.rs-105889/v2

License: (c) (i) This work is licensed under a Creative Commons Attribution 4.0 International License.

Read Full License

Version of Record: A version of this preprint was published at Journal of Cheminformatics on December 1st, 2021. See the published version at https://doi.org/10.1186/s13321-021-00574-4. 


\section{Abstract}

The authors have requested that this preprint be withdrawn due to erroneous posting.

\section{Full Text}

The authors have withdrawn this preprint from Research Square. 